\title{
Anti-hyperprolactinemic effect of Ficus pumila Linn extract in rats
}

\author{
Xiu-guo He ${ }^{1}$, Jiu-bo Fan ${ }^{2}$, Hai-ju Liu ${ }^{3}$ and Ning Xia ${ }^{4 *}$ \\ ${ }^{1}$ Department of Pharmacy, Suizhou Central Hospital, Suizhou, Hubei, China 441316, ${ }^{2}$ Clinical Laboratory, ${ }^{3}$ Department of \\ Ophthalmology, ${ }^{4}$ Department of Pharmacy, Xiangyang Central Hospital, Xiangyang, Hubei, China 441021 \\ *For correspondence: Email: hexiuguo133494@163.com; Tel: +86 07103523486
}

\begin{abstract}
Purpose: To investigate the anti-hyperprolactinemic effect of Ficus pumila Linn. extract (FPLE) in rats. Methods: Hyperprolactinemic rats were generated by subcutaneous injection of metoclopramide dihydrochloride (50 mg/kg). A high dose (800 mg/kg), moderate dose (400 mg/kg), or low dose (200 $\mathrm{mg} / \mathrm{kg}$ ) of FPLE was administered into the stomach of hyperprolactinemic rats for 30 days, after which serum sex hormones and pituitary prolactin-positive cell number and mRNA expression were measured. Results: FPLE had a significant effect on measures of hyperprolactinemia. Compared with hyperprolactinemic rats without FPLE treatment, hyperprolactinemic rats that received a high dose of FPLE showed altered serum estradiol, progesterone, prolactin, follicle-stimulating hormone, and luteinizing hormone levels $(p<0.05)$, as well as decreased pituitary prolactin-positive cell number $(p<$ $0.05)$ and $m R N A$ expression $(p<0.05)$.

Conclusion: FPLE can potentially be used as an anti-hyperprolactinemia treatment but further studies are required to ascertain its suitability.
\end{abstract}

Keywords: Ficus pumila, Hyperprolactinemia, Prolactin, Metoclopramide, Estradiol, Follicle-stimulating and luteinizing hormones, Sex hormones

Tropical Journal of Pharmaceutical Research is indexed by Science Citation Index (SciSearch), Scopus, International Pharmaceutical Abstract, Chemical Abstracts, Embase, Index Copernicus, EBSCO, African Index Medicus, JournalSeek, Journal Citation Reports/Science Edition, Directory of Open Access Journals (DOAJ), African Journal Online, Bioline International, Open-J-Gate and Pharmacy Abstracts

\section{INTRODUCTION}

Hyperprolactinemia, defined as a prolactin (PRL) level greater than $25 \mathrm{ng} / \mathrm{ml}$, is one of the most common endocrine disorders of the hypothalamus-pituitary axis in young women. It is associated with galactorrhea and ovulatory dysfunction, resulting in menstrual irregularities and bareness [1]. Hyperprolactinemia can occur at any age, and its prevalence varies from $0.4 \%$ in the normal adult population to $9-17 \%$ in women with menstrual problems such as amenorrhea or polycysticovarian syndrome [2,3]. Causes of hyperprolactinemia include hypothalamus-pituitary lesions, pituitary tumors, severe liver or kidney disease, neuritis or irritations of the spinal cord, depression, or other physiological factors such as pregnancy and lactation [4,5]. The pharmacological agents currently used to treat hyperprolactinemia cause many side effects, such as menstrual disorder, and are associated with high relapse rates. Although bromocriptine and cabergoline are effective in treating hyperprolactinemia, they are very expensive [7], and $12 \%$ patients cannot tolerate bromocriptine [6].

Since the Song Dynasty, Ficus pumila Linn. has been used to effectively treat Chinese women with galactorrhea without toxic side effects [8-9]. Therefore, we evaluated the anti-hyperprolactinemic effect of Ficus pumila Linn. extract 
(FPLE) on serum sex hormone levels and pituitary prolactin (PRL)-positive cell number and mRNA expression in rats.

\section{EXPERIMENTAL}

\section{Materials}

Herbal samples of Ficus pumila Linn. were collected from Bozhou City, Anhui Province, China in July, 2014. Taxonomic identification of the plant was performed by Professor YanSu of Suizhou Central Hospital in China. A specimen of the herb (no. FPLE 201407028) was deposited in the Department of Pharmacy, Suizhou Central Hospital, China for future reference. Dried Ficus pumila Linn. was steeped in water and extracted at $60{ }^{\circ} \mathrm{C}$ three times for $1 \mathrm{~h}$ each. The final extract was dried in an oven and freeze-dried. An aqueous extract of Ficus pumila Linn. was then obtained. One gram powder was equivalent to $1.8 \mathrm{~g}$ crude sample. The yield was $55.6 \%$.

Metoclopramide was purchased from Xuzhou Laien Pharmaceutical Co. Ltd. Bromocriptine was obtained from Novartis Pharma Schweiz AG. Other reagents were of analytical pure grade.

\section{Animals}

Female virgin Wistar rats weighing 200-220 g were provided by the Experimental Animal Center of Hubei Province (Certificate no. SYXK2007-0005). The animals had free access to food and water and were allowed to acclimatize for at least 1 week before use. Animal experiments were approved by the Animal Care and Use Committee of Suizhou Central Hospital (approval no. 20120805) and were carried out in compliance with Directive 2010/63/EU on the Handling of Animals used for Scientific Purposes [10].

\section{Preparation of hyperprolactinemic rats and FPLE treatment}

Hyperprolactinemic rats were generated as previously described with slight modifications [11]. Metoclopramide dihydrochloride $(50 \mathrm{mg} / \mathrm{kg})$ was subcutaneously injected into the back of rats. Injections were performed twice a day for 5 consecutive days.

Rats were divided into six groups ( $n=10$ per group): normal control, model (i.e., hyperprolactinemic), model plus bromocriptine, model plus high dose of FPLE (800 mg/kg), model plus moderate dose of FPLE $(400 \mathrm{mg} / \mathrm{kg})$, and model plus low dose of FPLE $(200 \mathrm{mg} / \mathrm{kg})$.
Each dose of FPLE was dissolved in $2 \mathrm{ml}$ water and administered through the mouth to the stomach by a syringe. The dosage for rats was calculated from the human clinical daily dosage of FPLE based on differences in body surface area. Control and model rats received $2 \mathrm{ml}$ of water only. All rats received intragastric administration for 30 days.

\section{Measurements of serum sex hormones}

After intragastric administration for 30 days, serum estradiol (E2), progesterone (P), PRL, follicle-stimulating hormone (FSH), and luteinizing hormone (LH) were measured. All measurements were performed using ELISA kits from Nanjing Jiancheng Inc. (China).

\section{Quantification of pituitary PRL-positive cells}

Rat pituitary tissue was embedded in paraffin wax. After dewaxing, tissue was incubated with 3 $\% \mathrm{H}_{2} \mathrm{O}_{2}$ for $5 \mathrm{~min}$ at room temperature. Anti-rat PRL antibody (primary antibody, 1:300) was applied for $60 \mathrm{~min}$ at room temperature, and tissue was washed with phosphate-buffered saline (PBS) three times. Next, tissue was incubated in EnVision reagent including secondary and tertiary antibodies for $60 \mathrm{~min}$ at room temperature and washed with PBS three times. Tissue was stained with DAB solution, washed with distilled water, and restained. PRLpositive cells were counted using Microsoft software at $200 \times$ magnification.

\section{Measurement of pituitary PRL mRNA expression}

Pituitary tissue was placed into a glass grinder with $1 \mathrm{ml}$ Trizol solution. The homogenate was placed into a 1.5-ml Eppendorf tube and kept at room temperature for $5 \mathrm{~min}$ before adding 0.25 $\mathrm{ml}$ chloroform, shaking for $15 \mathrm{~s}$, and resting for 3 $\min$ at room temperature. The solution was centrifuged $(12000 \times \mathrm{g})$ for $15 \mathrm{~min}$ at $4{ }^{\circ} \mathrm{C}$. The upper aqueous portion was added to an equal volume of isopropyl alcohol in a 1.5-ml Eppendorf tube and kept for $10 \mathrm{~min}$ at room temperature before centrifugation $(12000 \times \mathrm{g})$ for $10 \mathrm{~min}$ at $4{ }^{\circ} \mathrm{C}$.

The supernatant was discarded, $0.9 \mathrm{ml} 75 \%$ ethanol was added, and the solution was centrifuged $(10000 \times \mathrm{g})$ for $5 \mathrm{~min}$ at $4{ }^{\circ} \mathrm{C}$; this step was repeated once. The supernatant was discarded, and the precipitant was dried at room temperature. Next, 30 - $50 \mu \mathrm{l}$ RNase-free water was added to dissolve the RNA sample. The RNA sample and primer underwent PCR at 95 ${ }^{\circ} \mathrm{C}$ for $3 \mathrm{~min}$, and then $5 \mu \mathrm{l} 5 \times$ buffer, $5 \mu \mathrm{dNTP}$, 
$1 \mu \mathrm{l}$ RNA enzyme inhibitor, and $1 \mu \mathrm{l}$ M-MLV reverse transcriptase were successively added in an ice-bath. The reverse transcriptase was inactivated at $42{ }^{\circ} \mathrm{C}$ for $60 \mathrm{~min}$ and $95{ }^{\circ} \mathrm{C}$ for 2 min. The PCR amplification system consisted of $12.5 \mu \mathrm{l}$ PCR mix, $2 \mu \mathrm{l}$ rat PRL primers, $2 \mu \mathrm{l}$ internal primer, $2 \mu \mathrm{l}$ reverse transcription product, and RNase-free water.

The solution was centrifuged and mixed, and a small amount of sterile liquid paraffin was added for $3 \mathrm{~min}$ at $94{ }^{\circ} \mathrm{C}$. PCR amplification was carried out as follows: $94{ }^{\circ} \mathrm{C}$ for $30 \mathrm{~s}, 56{ }^{\circ} \mathrm{C}$ for $30 \mathrm{~s}$, and $72{ }^{\circ} \mathrm{C}$ for $60 \mathrm{~s}$ for 23 cycles. The last cycle was extended to $8 \mathrm{~min}$ at $72{ }^{\circ} \mathrm{C}$. The amplification product was placed on $1.5 \%$ agarose gel for 20 min for $70 \mathrm{~V}$ constant voltage electrophoresis, and the gray value of the sample was determined using a UVP computer image analysis system. Using $\beta$-actin as an internal control, the relative amount of pituitary PRL mRNA expression was measured.

\section{Statistical analysis}

Data are shown as mean \pm standard error of the mean unless otherwise indicated. Differences between groups were analyzed using one-way analysis of variance (ANOVA) followed by Student's t-tests. A $p$-value $<0.05$ was considered statistically significant.

\section{RESULTS}

\section{Effect of FPLE on serum sex hormones levels}

Rats in the model group showed significantly higher serum PRL levels $(p<0.01)$ and lower E2 $(p<0.01), \mathrm{P}(p<0.01)$, FSH $(p<0.01)$, and LH $(p<0.05)$ levels than rats in the control group (Table 1). The increased PRL levels in model rats were significantly attenuated by treatment with bromocriptine $(p<0.01)$, a moderate dose of FPLE $(p<0.01)$, or a high dose of FPLE $(p<$ 0.01). Bromocriptine, a moderate dose of FPLE, and a high dose of FPLE also significantly increased E2 $(p<0.01), \mathrm{P}(p<0.01), \mathrm{FSH}(p<$ $0.05)$, and LH $(p<0.05)$ levels.

\section{Effect of FPLE on pituitary PRL-positive cell number}

The number of pituitary PRL-positive cells was significantly higher in model rats than in control rats $(p<0.01$; Figure 1$)$. This increased number of PRL-positive cells in model rats was significantly attenuated by treatment with bromocriptine $(p<0.01)$, a moderate dose of FPLE $(p<0.05)$, and a high dose of FPLE $(p<$ $0.01)$.

Table 1: Effect of FPLE on serum sex hormones levels

\begin{tabular}{|c|c|c|c|c|c|}
\hline Group & PRL (pg/ml) & E2 (pmol/l) & $P(\mathrm{ng} / \mathrm{ml})$ & FSH (IU/I) & LH (mlU/ml) \\
\hline Control & $223.54 \pm 6.52$ & $3.06 \pm 0.32$ & $1.03 \pm 0.05$ & $0.97 \pm 0.06$ & $1.71 \pm 0.13$ \\
\hline Model & $432.14 \pm 35.57^{\pi \pi}$ & 1. $36 \pm 0.18^{\pi \pi}$ & $0.24 \pm 0.15^{\pi \pi}$ & $0.36 \pm 0.04^{\pi \pi}$ & $0.97 \pm 0.06^{\pi}$ \\
\hline BMT & $231.69 \pm 11.71 \Delta \Delta$ & $2.56 \pm 0.26 \Delta \Delta$ & $0.73 \pm 0.03 \Delta$ & $0.71 \pm 0.02^{\Delta}$ & $1.62 \pm 0.05^{\Delta}$ \\
\hline FPLE-H & $229.15 \pm 11.51 \Delta \Delta$ & $2.45 \pm 0.15^{\Delta \Delta}$ & $0.91 \pm 0.05^{\Delta}$ & $0.76 \pm 0.02^{\Delta}$ & $1.71 \pm 0.21 \Delta$ \\
\hline FPLE-M & $241.62 \pm 14.62 \Delta \Delta$ & $2.24 \pm 0.38 \Delta$ & $0.81 \pm 0.06 \Delta$ & $0.70 \pm 0.03 \Delta$ & $1.51 \pm 0.04 \Delta$ \\
\hline FPLE-L & $304.26 \pm 47.22$ & $1.91 \pm 0.46$ & $0.38 \pm 0.11$ & $0.42 \pm 0.07$ & $1.02 \pm 0.12$ \\
\hline
\end{tabular}

${ }^{*} p<0.05, \quad{ }^{* *} p<0.01$ vs. control group; $\Delta p<0.05, \Delta \Delta p<0.01$ vs. model group. Values are shown as mean \pm standard deviation. FPLE-H: high dose of FPLE; FPLE-M: moderate dose of FPLE; FPLE-L: low dose of FPLE; BMT: bromocriptine

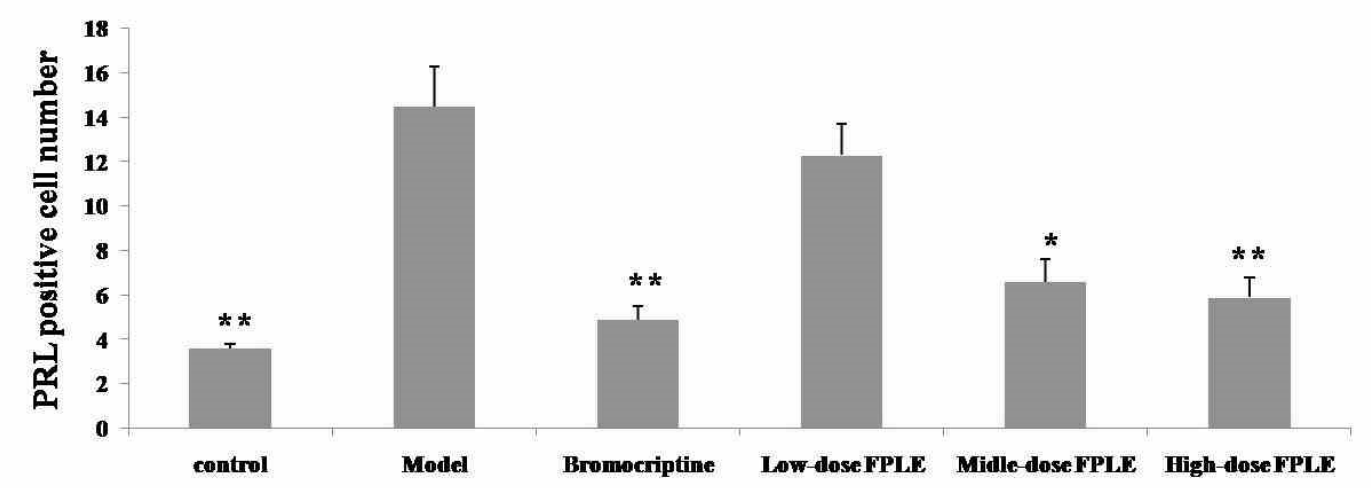

Figure 1: Pituitary PRL-positive cell numbers. ${ }^{*} p<0.05,{ }^{* *} p<0.01$ vs. model group 


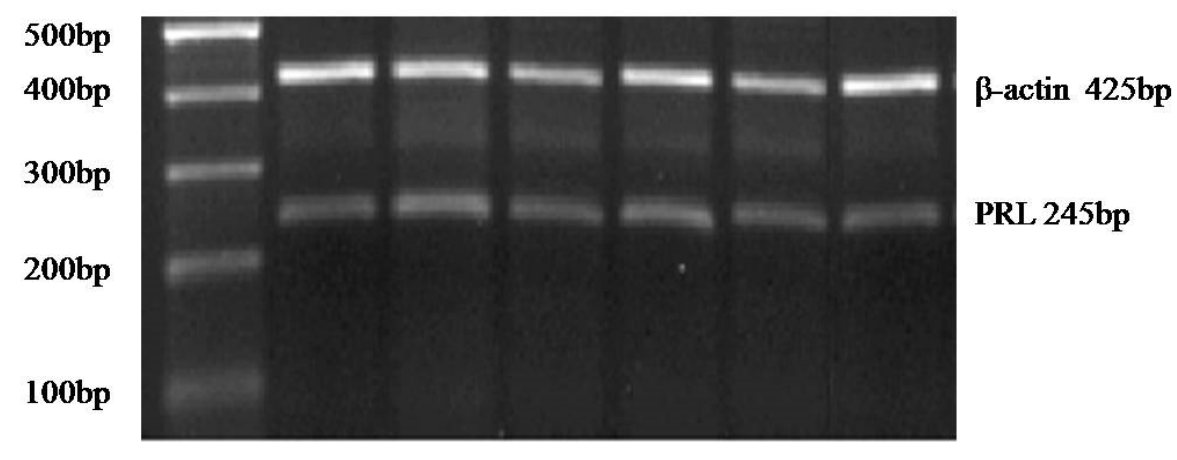
$\mathrm{M}$
A
$\mathrm{B}$
C D
E $\quad \mathrm{F}$

Figure 2: Pituitary PRL mRNA expression measured by RT-PCR. M: Marker; A: Control group; B: Model group; C: Bromocriptine group; D: Low dose of FPLE group; E: Moderate dose of FPLE group; F: High dose of FPLE group.

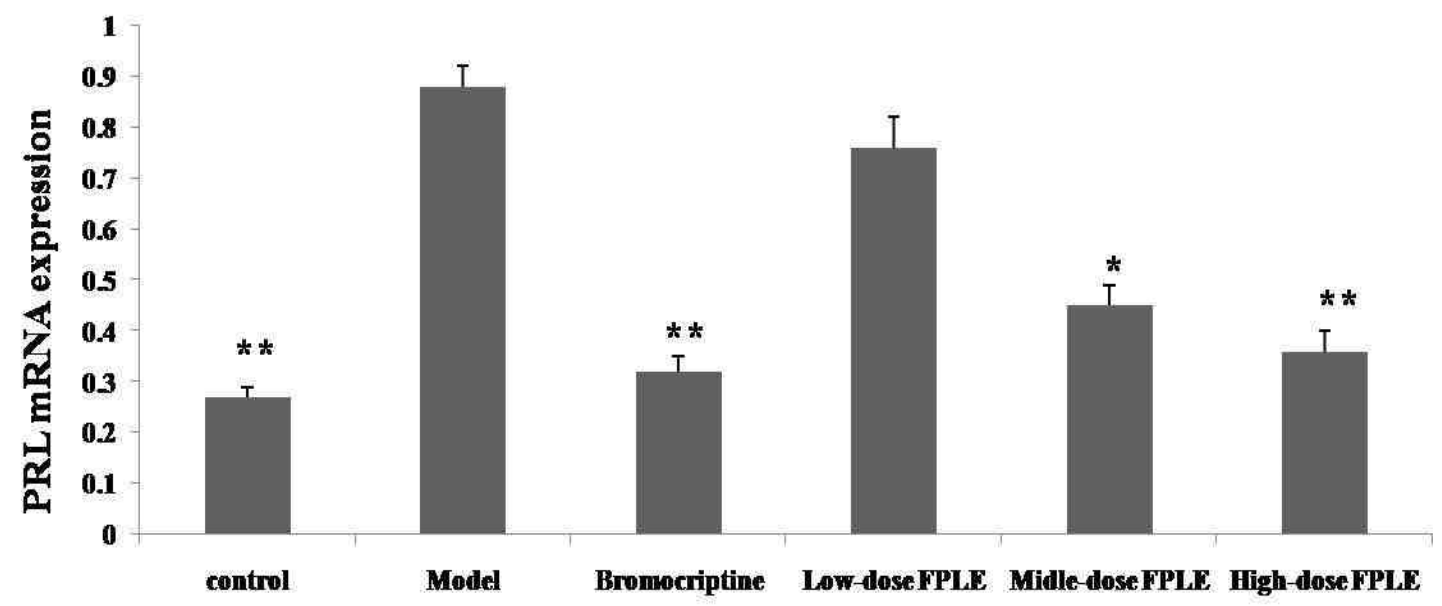

Figure 3: Relative amount of pituitary PRL mRNA expression. ${ }^{*} p<0.05,{ }^{* *} p<0.01$ vs. model group

\section{Effect of FPLE on pituitary PRL MRNA expression}

Model rats showed significantly higher $\mathrm{PRL}$ mRNA expression than control rats $(p<0.01$; Figures 2-3). This increased PRL mRNA expression in model rats was significantly attenuated by treatment with bromocriptine $(p<$ $0.01)$, a moderate dose of FPLE $(p<0.05)$, and a high dose of FPLE $(p<0.01)$.

\section{DISCUSSION}

The hypothalamus-pituitary-gonadal axis plays an important role in maintaining normal physiological body function and homeostasis of the internal environment [12]. However, external factors can lead to abnormal sex hormone secretion and result in conditions such as hyperprolactinemia, hyperplasia of the mammary gland, hysteromyoma, and infertility. In mammals, PRL regulates mammogenesis, promotes milk production, and initiates and sustains lactation through autocrine and paracrine signaling $[13,14]$. PRL has many functions in breast tissue, including uridine conversion, milk protein synthesis, mammary cell sodium transport, incorporation into DNA, and breast fatty acid synthetase activity [15]. We found that hyperprolactinemic rats showed higher serum PRL concentrations, as well as lower E2, $\mathrm{P}, \mathrm{FSH}$, and $\mathrm{LH}$ concentrations than control rats. However, FPLE attenuated the effects of hyperprolactinemia on serum sex hormone levels, suggesting that FPLE improves ovary function and reduces hyperplasia of the lobules and gland alveolus. Furthermore, FPLE decreased pituitary PRL-positive cell number and mRNA expression in hyperprolactinemic rats.

\section{CONCLUSION}

The results confirm that Ficus pumila Linn. has curative effects in hyperprolactinemia and suggest that FPLE treatment can regulate serum E2, P, PRL, FSH, and LH levels and decrease pituitary PRL-positive cell number and mRNA expression in women with hyperprolactinemia. Therefore, FPLE should be developed as an antihyperprolactinemia treatment in future work. 


\section{DECLARATIONS}

\section{Acknowledgement}

The authors thank Professor Ting Li of Wuhan University for assistance with PCR analysis.

\section{Conflict of Interest}

No conflict of interest associated with this work.

\section{Contribution of Authors}

The authors declare that this work was done by the authors named in this article and all liabilities pertaining to claims relating to the content of this article will be borne by them.

\section{REFERENCES}

1. Lee $D-Y$, Oh K-L, Yoon B-K. Prevalence of hyperprolactinemia in adolescents and young women with menstruation-related problem. Am $J$ Obstet Gynecol 2012; 213: e1-5.

2. Biller BM, Luciano A, Crosignani PG. Guidelines for the diagnosis and treatment of hyperprolactinemia. $J$ Reprod Med 1999; 44: 1075-1084.

3. Greer ME, Moraczewski T, Rakoff JS. Prevalence of hyperprolactinemiain anovulatory women. Obstet Gynecol 1980; 56: 65-69.

4. Gerhard Lutz. Hair loss and hyperprolactinemia in women. Dermato-Endocrinol 2012; 4: 73.
5. Yu-lee $L Y, L u o G Y$, Book ML. Lactogenic hormone signal transduction. Biol Reprod 1998; 58: 295-301.

6. Webster J, Piscitell G, Polli A. A Comparison of Cabergoline and Bromocriptine in the Treatment of Hyperprolactinemic Amenorrhea. N Engl J Med 1994; 331: 904-909.

7. Mah PM, Webster J. Hyperprolactinemia: etiology, diagnosis and management. Semin Reprod Med 2002; 20: 365-374

8. Zhu Dong-qing. The effect observation of Ficus pumila Linn in delactation, Zhej J Trad Chin Med 2010; 44: 883.

9. Guo Xiao-dong, Guo Bin-zhang. The effect and mechanism of different processing Ficus pumila Linn. on delectation. J North China Coal Med Uni 2006; 8: 658659.

10. European Commission [homepage on the internet]. Directive 2010/63/EU on the protection of animals used for scientific purposes [cited 2013 Jan 16]. Available from:http://ec.europa.eu/environment/chemicals/lab_ani mals/legislation_en.htm.

11. Lin KC, Kawamura N, Okamura $H$. Inhibition of ovalation, steroidogenesis and collagenolytic activity in rabbits by sulpiride-induced hyperprolactinemia. J. Reprod Fert 1988; 83: 612-613.

12. Goya RG. The immune-neuroendocrine homeostatic network and aging. Gerontology 1991; 37: 208-213.

13. Freeman ME, Kanyicska B, Lerant A. Prolactin: structure, function, and regulation of secretion. Physiol Rev 2000; 80: 1523-1526.

14. Kelley KW, Weigent DA, Kooijman R. Protein hormones and immunity. Brain Behav Immun 2007; 21: 384-392.

15. Malarkey WB, Schroeder LL, Stevens VC. Disordered nocturnal prolactin regulation in women with breast cancer. Cancer Res 1977; 37: 4650. 